\title{
Biodegradation of lignin in a compost environment: a review
}

\author{
M. Tuomela ${ }^{\mathrm{a}}$, M. Vikman ${ }^{\mathrm{b}}$, A. Hatakka ${ }^{\mathrm{a}, *}$, M. Itävaara ${ }^{\mathrm{b}}$ \\ ${ }^{a}$ Department of Applied Chemistry and Microbiology, University of Helsinki, P.O. Box 56 (Biocenter 1), FIN-00014 Helsinki, Finland \\ ${ }^{\mathrm{b}}$ VTT Biotechnology and Food Research, P.O. Box 1501, FIN-02044 VTT, Finland
}

Received 16 November 1998; received in revised form 8 May 1999; accepted 25 May 1999

\begin{abstract}
Composting is nowadays a general treatment method for municipal solid waste. Compostable household waste contains, together with vegetable material, varying amounts of papers and boards. In the European Union composting is regarded as one recycling method for packages and this will probably favour compostable packages, like papers and boards, in the future. Paper is made up of lignocellulose and it may contain up to $20 \%$ of lignin. Efficient degradation of papers in composting plants means that biodegradation of lignin is also needed. However, very little is known about lignin degradation by mixed microbial compost populations, although lignin degradation by white-rot fungi has been extensively studied in recent years. Organic material is converted to carbon dioxide, humus, and heat by compost microorganisms. It is assumed that humus is formed mainly from lignin. Thus, lignin is not totally mineralized during composting. The elevated temperatures found during the thermophilic phase are essential for rapid degradation of lignocellulose. Complex organic compounds like lignin are mainly degraded by thermophilic microfungi and actinomycetes. The optimum temperature for thermophilic fungi is $40-50^{\circ} \mathrm{C}$ which is also the optimum temperature for lignin degradation in compost. (C) 1999 Elsevier Science Ltd. All rights reserved.
\end{abstract}

Keywords: Lignin; Lignocellulose; Compost; Biodegradation; Thermophilic fungi

ABR: CEL: cellulase enzyme lignin ; DHP: dehydrogenation polymer (synthetic lignin); FTIR: Fourier transform infra red; LiP: lignin peroxidase; MnP: manganese peroxidase; MWL: milled wood lignin; NMR: nuclear magnetic resonance

\section{Introduction}

Paper and board are the best recycled materials in Europe. More than $40 \%$ of the total production is collected and recycled annually, and the proportion of recycling is constantly growing. Corrugated board forms the best recovered part of paper and board and, furthermore, almost half of all recycled fibres are used for manufacturing corrugated board while $12 \%$ is used for manufacturing newspaper (Goddard, 1997; LeppänenTurkula, 1999).

According to the European Union Packaging and Packaging Waste Directive (1994) by the year $200125-$ $45 \%$ of packaging waste must be recycled. This target can be met with paper and board, but in some cases, recycling as material is not environmentally sound. Then one option would be composting. 'Recycling' means 'reprocessing', including composting. Packaging, like

\footnotetext{
${ }^{*}$ Corresponding author. Tel.: +358-9-7085-9314; fax: +358-9-70859322.

E-mail address: annele.hatakka@helsinki.fi (A. Hatakka)
}

paper products and newly developed biodegradable plastics, can be collected directly from consumers along with kitchen biowaste and composted in municipal composting plants, provided that they are compostable under such conditions (Itävaara et al., 1997). In recent years intensive research has been focused on the development of biodegradable plastics (Albertsson and Karlsson, 1995; Forssell et al., 1996; Itävaara et al., 1997), but relatively little attention has been paid to the biodegradability and compostability of paper products. More information is needed about the biodegradation of paper products in a compost environment, information about lignin degradation is especially important, because lignin is a recalcitrant polymer and paper may contain up to $20 \%$ of lignin (Biermann, 1993).

The European standardization organization, CEN, is developing test methods and recently finalized a test scheme for the evaluation of the compostability of various packaging materials (CEN TC261, SC4, WG2, draft, 1998). In the scheme the biodegradability of organic components is studied using mineralization and disintegration measurements. Wood fibres shall be 
accepted as being biodegradable, because of their natural origin, but must fulfil the criteria for disintegration and compost quality (CEN TC261,SC4,WG2, draft, 1998; Pagga, 1999).

What is currently known about the biodegradability and compostability of lignocellulosic materials - especially lignin - is reviewed in this literature survey. Microbial activity during composting is also briefly reviewed. The main emphasis is placed on thermophilic fungi because they occur frequently in compost and fungi, especially white-rot fungi, are also the most important group of lignin biodegraders in nature.

\section{Lignocellulose}

In nature, lignocellulose accounts for the major part of biomass and, consequently, its degradation is essential for the operation of the global carbon cycle (Fig. 1). Lignocellulose, such as wood, is mainly composed of a mixture of cellulose (ca. 40\%), hemicellulose (ca. 2030\%), and lignin (ca. 20-30\%) (Sjöström, 1993). Lignin is an integral cell wall constituent, which provides plant strength and resistance to microbial degradation (Argyropoulos and Menachem, 1997).

\subsection{Lignin in biodegradation studies}

The macromolecular properties and structural characteristics of lignin make biodegradation studies diffi- cult. Suitable model compounds of lignin are difficult to obtain and there are only a few assays which are suitable for biodegradation studies (Buswell and Odier, 1987).

The ideal isolation method of lignin would allow the collection of chemically unmodified lignin with quantitative recovery and free of non-lignin contaminants (Lin and Dence, 1992). None of the existing methods fulfil all these requirements. Some of the methods are more suitable for quantitative lignin analysis, and others can be used to isolate lignin for purposes such as biodegradation studies (Table 1). Milled wood lignin (MWL) (= Björkman lignin) and cellulase enzyme lignin (CEL) are the best matrices for the structural analysis of lignin. However, they are not suitable for quantitative measurement because of their low yields of lignin (Sjöström, 1993; Argyropoulos and Menachem, 1997). The methods used for isolating lignin can be classified into methods in which lignin is selectively removed and recovered from the final solution, and methods in which lignin is left as an insoluble residue following dissolution of the carbohydrates. Determination of Kappa number and Klason lignin are the most common methods used to analyse lignin quantitatively. Kappa number is an important parameter in the pulp and paper industry and it is determined by oxidizing lignin selectively from pulp using a solution of potassium permanganate (Argyropoulos and Menachem, 1997). Klason lignin is determined gravimetrically after extracting the sample with sulphuric acid to dissolve out the other components (Dence, 1992).

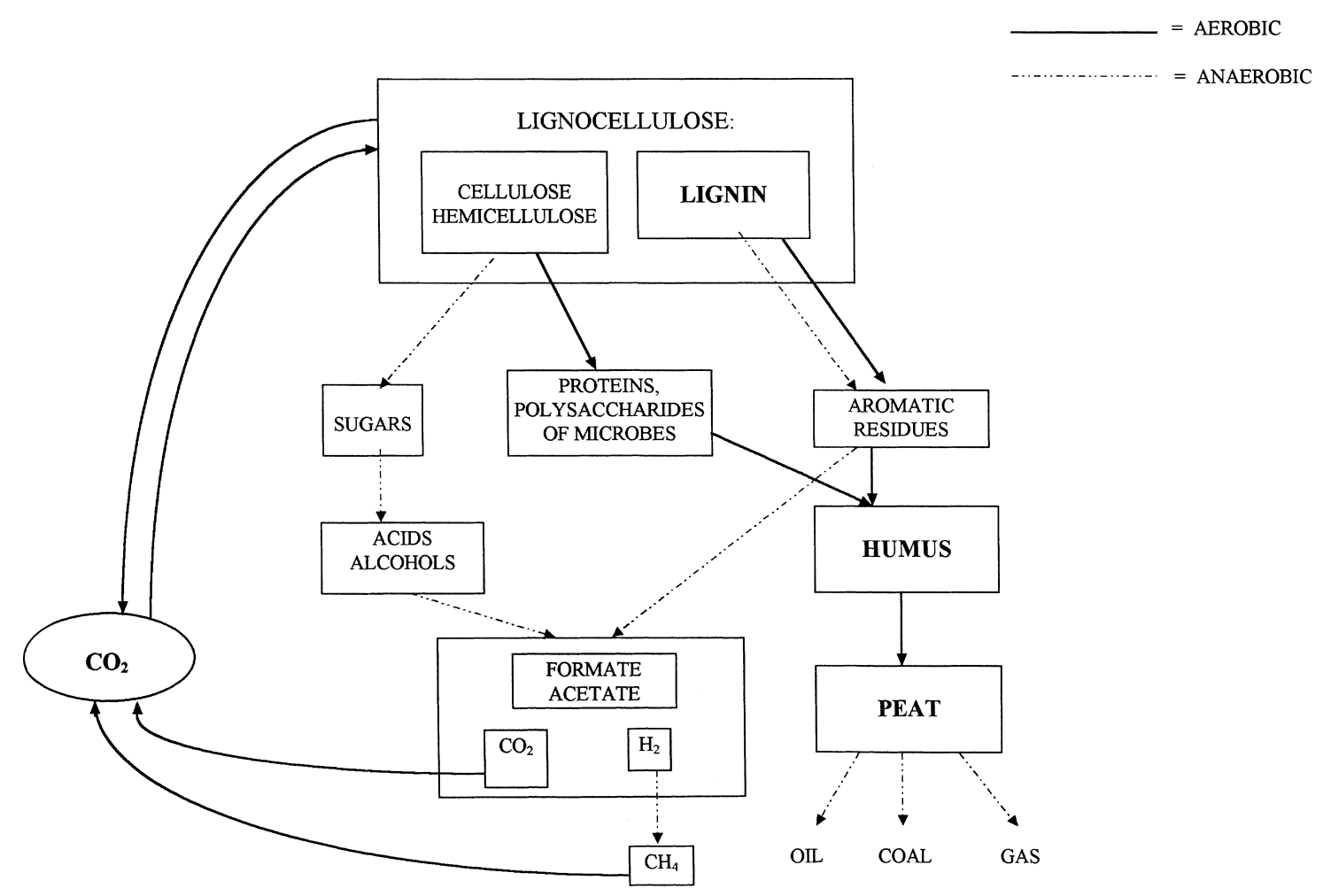

Fig. 1. Global carbon cycle (Brown, 1985; Colberg, 1988). 
Table 1

Commonly utilized methods for analyzing, isolating, and synthesizing lignin (Buswell and Odier, 1987; Dence, 1992; Argyropoulos and Menachem, 1997)

\begin{tabular}{|c|c|c|c|}
\hline Name & Principle of the method & Advantages & Disadvantages \\
\hline \multicolumn{4}{|c|}{ Quantitative measurement of lignin } \\
\hline $\begin{array}{l}\text { Klason lignin } \\
\text { Acid-insoluble lignin }\end{array}$ & $\begin{array}{l}\text { Residue after treatment of sample } \\
\text { with } 72 \% \text { sulphuric acid }\end{array}$ & $\begin{array}{l}\text { Suitable for a wide range of } \\
\text { samples }\end{array}$ & $\begin{array}{l}\text { Structure different from that of } \\
\text { lignin }\end{array}$ \\
\hline Acetyl bromide method & $\begin{array}{l}\text { Lignin is dissolved in acetyl } \\
\text { bromide-acetic acid, the amount of } \\
\text { lignin measured from the absorbance } \\
\text { at } 280 \mathrm{~nm}\end{array}$ & $\begin{array}{l}\text { Rapid, simple, adaptable for } \\
\text { small amounts of sample, } \\
\text { minimal chemical } \\
\text { modification of sample }\end{array}$ & $\begin{array}{l}\text { Solubility of bleached pulps can } \\
\text { be incomplete, oxidation during } \\
\text { bleaching of the pulp can change } \\
\text { the spectral absorption } \\
\text { characteristics of the lignin }\end{array}$ \\
\hline Kappa number & $\begin{array}{l}\text { The amount of oxidant (potassium } \\
\text { permanganate) consumed by sample } \\
\text { corresponds to the amount of } \\
\text { residual lignin }\end{array}$ & Rapid, simple & $\begin{array}{l}\text { Used mainly in quality control in } \\
\text { commercial pulping }\end{array}$ \\
\hline \multicolumn{4}{|l|}{ Isolation of lignin } \\
\hline $\begin{array}{l}\text { Milled wood lignin } \\
(\mathrm{MWL}=\text { Björkman lignin) }\end{array}$ & $\begin{array}{l}\text { Ultramilling of wood and } \\
\text { extraction with neutral solvents } \\
\text { followed by precipitation in water and } \\
\text { ethyl ether }\end{array}$ & $\begin{array}{l}\text { Best representation of native } \\
\text { lignin, macromolecular }\end{array}$ & $\begin{array}{l}\text { Low yield, preparation time- } \\
\text { consuming and cumbersome, } \\
\text { some contaminating sugars }\end{array}$ \\
\hline $\begin{array}{l}\text { Cellulase enzyme lignin } \\
\text { (CEL) }\end{array}$ & Cellulase enzyme treatment & $\begin{array}{l}\text { Good representation of native } \\
\text { lignin, macromolecular }\end{array}$ & $\begin{array}{l}\text { Low yield, contains protein } \\
\text { impurities }\end{array}$ \\
\hline Kraft lignin & $\begin{array}{l}\text { Cooking in the presence of } \mathrm{NaOH} \\
\text { and } \mathrm{Na}_{2} \mathrm{SO}_{4}\end{array}$ & Easy availability & $\begin{array}{l}\text { Structure far from native lignin, } \\
\text { not entirely macromolecular, } \\
\text { contaminating sugars }\end{array}$ \\
\hline Brauns' lignin & Extraction with ethanol & $\begin{array}{l}\text { Easier preparation compared } \\
\text { to MWL }\end{array}$ & Low molecular weight \\
\hline \multicolumn{4}{|l|}{ Synthetic lignin } \\
\hline $\begin{array}{l}\text { Dehydrogenation polymer } \\
\text { (DHP) }\end{array}$ & $\begin{array}{l}\text { Synthesized from its precursors, } \\
\text { usually from coniferyl alcohol }\end{array}$ & $\begin{array}{l}\text { Good representation of native } \\
\text { lignin, macromolecular }\end{array}$ & Laborious synthesis \\
\hline
\end{tabular}

Lignin substructures and dimeric model compounds have been widely used in biodegradation studies because of the lack of good, or easily available, model compounds. Typical lignin models are the dimeric compounds which have the same linkages as found in lignin. The most important compounds are those with $\beta$-aryl ether linkages (Buswell and Odier, 1987; Kirk and Farrell, 1987). Aromatic acids such as veratric acid, vanillic acid and syringic acid have also been used as model compounds. The relevance of model compounds for understanding macromolecular lignin degradation has been criticized: the model compounds are water soluble and can be degraded by intracellular substratespecific enzymes that are different from the enzymes which attack complex water-insoluble lignin (Crawford and Crawford, 1980).

Dehydrogenation polymers (DHPs) are synthetic lignins made of the primary lignin precursors; i.e. cinnamyl alcohols, usually coniferyl alcohol. They have been widely used as model compounds and their chemical and physical properties are well characterized. During synthesis the precursors can be labelled in different positions for radioisotopic studies (Crawford et al., 1980; Hatakka, 1994). The use of preparations of radioactive lignins has solved many problems in lignin degradation studies. ${ }^{14} \mathrm{C}$-labelled lignins have made it possible to measure the fate of the ${ }^{14} \mathrm{C}$-label, i.e. to mineralized lignin, to solubilized lignin, etc., after microbial degradation. It is also possible to prepare specifically labelled lignins, e.g. the ${ }^{14} \mathrm{C}$-label can replace special carbons on the propane side chains or in aromatic rings (Crawford et al., 1980). Nonisotopic methods are usually restricted to qualitative lignin degradation studies because they provide only a rough estimation of the quantity of degraded lignin compared to the radioactive methods (Crawford et al., 1980).

\section{Microorganisms during composting}

\subsection{Compost environment}

During composting microorganisms transform organic matter into $\mathrm{CO}_{2}$, biomass, thermoenergy (heat) and humus-like end-product, (Figs. 1 and 2). The organic substrates, bulking agents and amendments used in composting are mostly derived from plant material. The main components of the organic matter are carbohydrates (e.g. cellulose), proteins, lipids and lignin. The capacity of microorganisms to assimilate organic matter depends on their ability to produce the enzymes needed for degradation of the substrate. The more complex the substrate, the more extensive and comprehensive is the enzyme system required. Through the synergistic action 


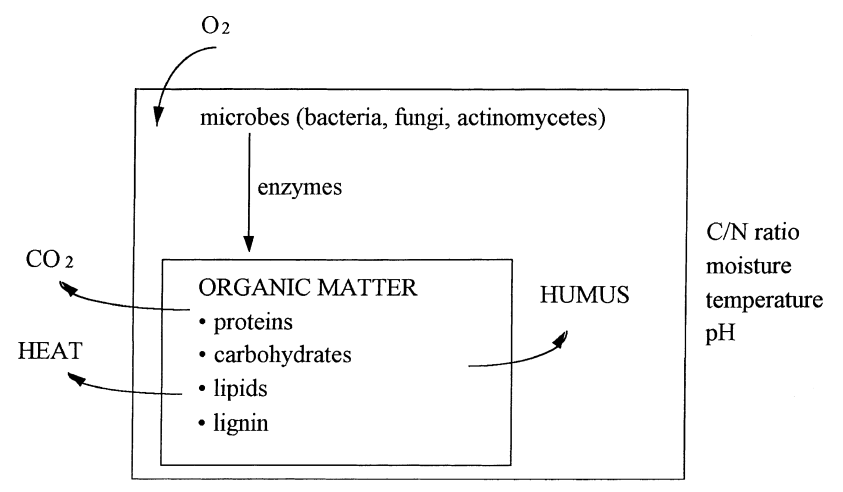

Fig. 2. The composting process (Itävaara et al., 1995).

of microorganisms complex organic compounds are degraded to smaller molecules which can then be utilized by the microbial cells (Golueke, 1991, 1992).

Microorganisms require a carbon source, macronutrients such as nitrogen, phosphorous and potassium, and certain trace elements for their growth. Carbon serves primarily as an energy source for the microorganisms, while a small fraction of the carbon is incorporated into their cells. Some of the energy formed is used for microbial metabolism, and the rest is released as heat. Nitrogen is a critical element for microorganisms because it is a component of the proteins, nucleic acids, amino acids, enzymes and co-enzymes necessary for cell growth and functioning. If nitrogen is a limiting factor during composting the degradation process will be slow. In contrast, if there is excess nitrogen, it is often lost from the system as ammonia gas or other nitrogen compounds. The optimum $\mathrm{C} / \mathrm{N}$ ratio has been reported to be $25-40$, but the value varies depending on the substrate (Golueke, 1991).

Microorganisms are able to use organic molecules which dissolve in water. If the moisture content falls below a critical level, microbial activity will decrease and the microbes become dormant. On the other hand, too high a moisture content can cause a lack of aeration and the leaching of nutrients. In the subsequent anaerobic conditions the decomposition rate decreases and odour problems arise (Golueke, 1991).

Under optimal conditions, composting proceeds through three phases: (1) the mesophilic phase, (2) the thermophilic phase, which can last from a few days to several months, and (3) the cooling and maturation phase which lasts for several months (Fig. 3). The length of the composting phases depends on the nature of the organic matter being composted and the efficiency of the process, which is determined by the degree of aeration and agitation. At the start of composting the mass is at ambient temperature and usually slightly acidic. Soluble and easily degradable carbon sources, such as monosaccharides, starch and lipids, are utilized by microorganisms in the early stage of composting. The $\mathrm{pH}$ decreases because organic acids are formed from these compounds during degradation. In the next stage microorganisms start to degrade proteins, resulting in the liberation of ammonium and an increase in the $\mathrm{pH}$. After the easily degradable carbon sources have been consumed, more resistant compounds such as cellulose, hemicellulose and lignin are degraded and partly transformed into humus (Crawford, 1983; Paatero et al., 1984).

Humus is the end product of the humification process, in which compounds of natural origin are partially transformed into relatively inert humic substances. Humic substances can be considered as a major reservoir of organic carbon in soils and aquatic environments (Aiken et al., 1985). The definitive structure of humic substances is not known, but they are usually divided into groups on the basis of chemical fractionation.

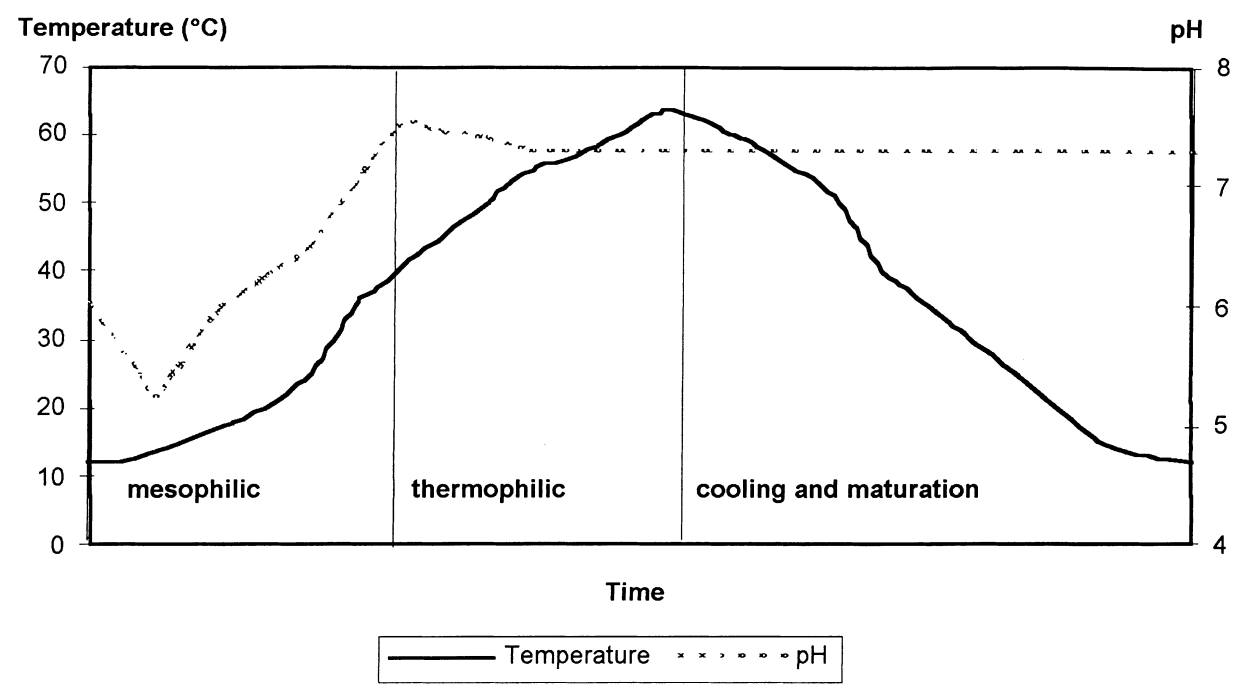

Fig. 3. Temperature and $\mathrm{pH}$ variation during natural composting process. The figure is redrawn from Golueke (1991). 
Organic matter present in compost is usually chemically complex and difficult to fractionate. Extraction procedures may remove only a fraction of the organic matter, and, consequently, nondestructive methods such as ${ }^{13} \mathrm{C}$ NMR (Almendros et al., 1992) and FTIR (Fourier transform IR) (Tseng et al., 1996) spectroscopy have been used for the analysis of humus. Aiken et al. (1985) divided humic substances into the following groups: humin (not soluble in water at any $\mathrm{pH}$ ), humic acids (not soluble in water under acidic conditions) and fulvic acids (soluble in water under all $\mathrm{pH}$ conditions).

In general, immature compost contains high levels of fulvic acids and low levels of humic acids. As the decomposition proceeds, the fulvic acid fraction either decreases or remains unchanged while humic acids are produced. The degree of humification and compost maturity can be evaluated by means of the humification index. The humification index is the ratio between humic acids and fulvic acids $\left(\mathrm{C}_{\mathrm{HA}} / \mathrm{C}_{\mathrm{FA}}\right)$ expressed as a percentage of the total organic carbon (Riffaldi et al., 1986; Inbar et al., 1990; Chen et al., 1996). Chen et al. (1996) studied the formation and properties of humic substances during composting. They found that the humification index increases during the process. The ${ }^{13} \mathrm{C}$-NMR spectra of humic acids have been used to study the presence of aliphatic and aromatic structures. Both ${ }^{13} \mathrm{C}$-NMR analysis and FTIR spectra indicate that the humic acid fraction extracted from a mature compost contains more aromatic structures and carboxyl groups and less carbohydrate components than that from an immature compost (Chen et al., 1996).

It has been claimed that humus is mainly formed from lignin, polysaccharides and nitrogenous compounds (Varadachari and Ghosh, 1984; Fustec et al., 1989; Inbar et al., 1989). The chemical pathway from organic matter to humus is very complex and involves a number of degradative and condensation reactions. Several schemes for the formation of humus have been proposed (e.g. Varadachari and Ghosh, 1984; Brown, 1985; Colberg, 1988). According to Varadachari and Ghosh (1984), lignin is first degraded by extracellular enzymes to smaller units, which are then absorbed into microbial cells where they are partly converted to phenols and quinones. The substances are discharged together with oxidizing enzymes into the environment, where they polymerized by a free-radical mechanism.

Composting is a dynamic process carried out by a rapid succession of mixed microbial populations. The main groups of microorganism involved are bacteria, including actinomycetes, and fungi (Golueke, 1991). Although the total number of microorganisms does not significantly change during composting, the microbial diversity can vary during the different phases of composting (Atkinson et al., 1996a). The precise nature of succession and the number of microorganims at each composting phase is dependent on the substrate and on the preceding microorganisms in the succession (Crawford, 1983).

At the beginning of composting mesophilic bacteria predominate, but after the temperature increases to over $40^{\circ} \mathrm{C}$, thermophilic bacteria take over and thermophilic fungi also appear in the compost. When the temperature exceeds $60^{\circ} \mathrm{C}$, microbial activity decreases dramatically, but after the compost has cooled mesophilic bacteria and actinomycetes again dominate (McKinley and Vestal, 1985; Strom, 1985a).

Composting is an aerobic process in general, but anaerobic microenvironments may develop. Atkinson et al. (1996b) estimated that almost $1 \%$ of all the bacteria found in municipal solid waste compost were anaerobic. All the anaerobic bacteria found were highly cellulolytic and thus may play a significant role in the degradation of macromolecules. The majority of the mesophilic anaerobic bacteria were facultative, while under thermophilic conditions more obligate anaerobic bacteria were found (Atkinson et al., 1996b).

\subsection{Bacteria}

Bacteria are typically unicellular with a size ranging from 0.5 to $3.0 \mu \mathrm{m}$. Because of their small size bacteria have a very high surface/volume ratio, which allows rapid transfer of soluble substrates into the cell. As a result, bacteria are usually far more dominant than larger microorganisms such as fungi. Some bacteria, e.g. Bacillus spp., are capable of producing thick-walled endospores which are very resistant to heat, radiation and chemical disinfection (Haug, 1993).

A wide range of bacteria have been isolated from different compost environments, including species of Pseudomonas, Klebsiella and Bacillus (Nakasaki et al., 1985; Strom, 1985a,b; Falcón et al., 1987). Typical bacteria of the thermophilic phase are species of Bacillus, e.g. B. subtilis, B. licheniformis and B. circulans. Strom (1985b) reports that as much as $87 \%$ of the randomly selected colonies during the thermophilic phase of composting belong to the genus Bacillus. Many thermophilic species of Thermus have been isolated from compost at temperatures as high as $65^{\circ} \mathrm{C}$ and even $82^{\circ} \mathrm{C}$ (Beffa et al., 1996).

Actinomycetes are bacteria which form multicellular filaments, thus they resemble fungi. They appear during the thermophilic phase as well as the cooling and maturation phase of composting, and can occasionally become so numerous that they are visible on the surface of the compost. Thermophilic actinomycetes have been isolated from a wide range of natural substrates, e.g. from desert sand and compost (Cross, 1968). The genera of the thermophilic actinomycetes isolated from compost include Nocardia, Streptomyces, Thermoactinomyces and Micromonospora (Waksman et al., 1939b; Strom, 1985a). Actinomycetes are able to degrade some 


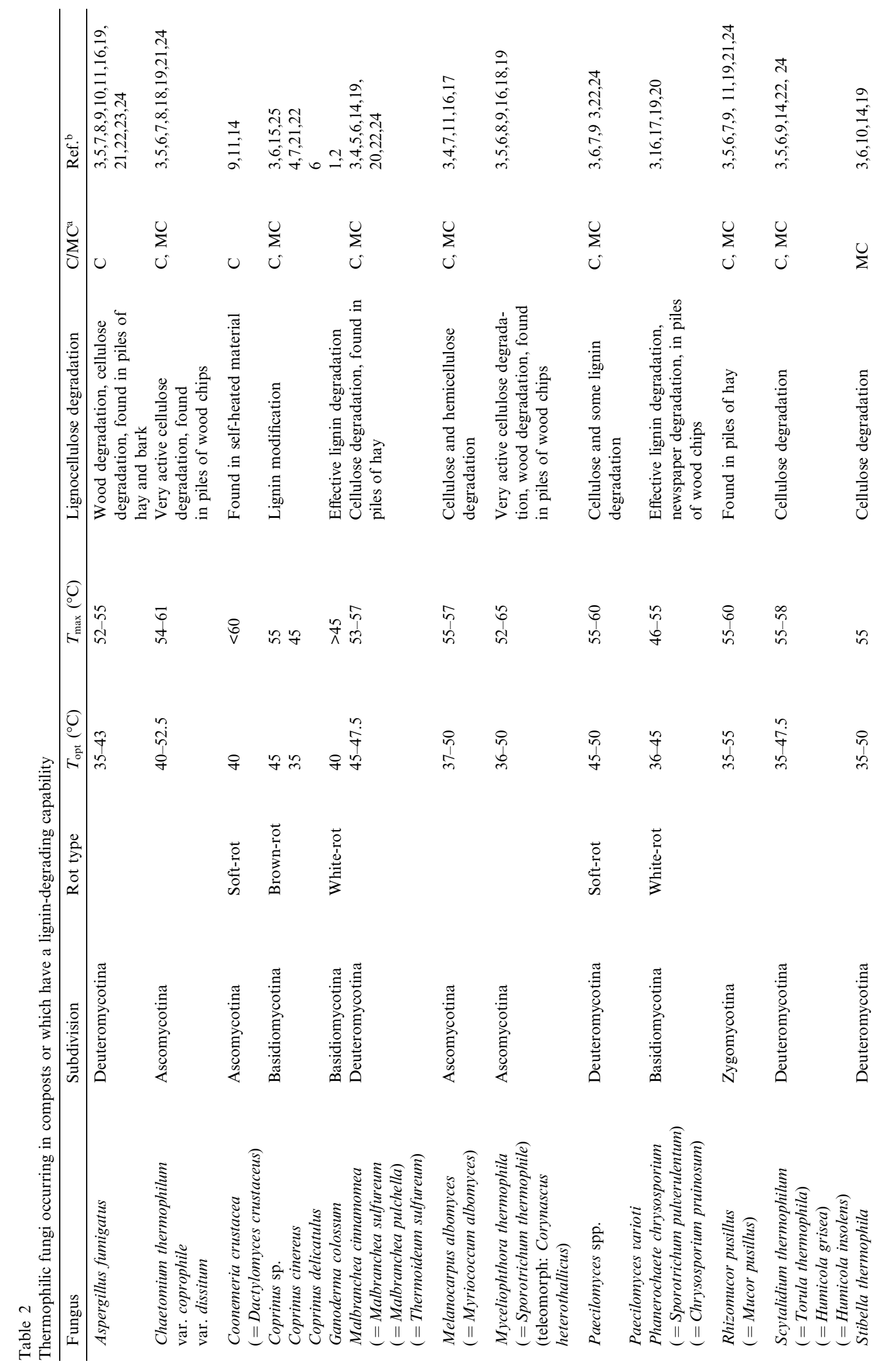




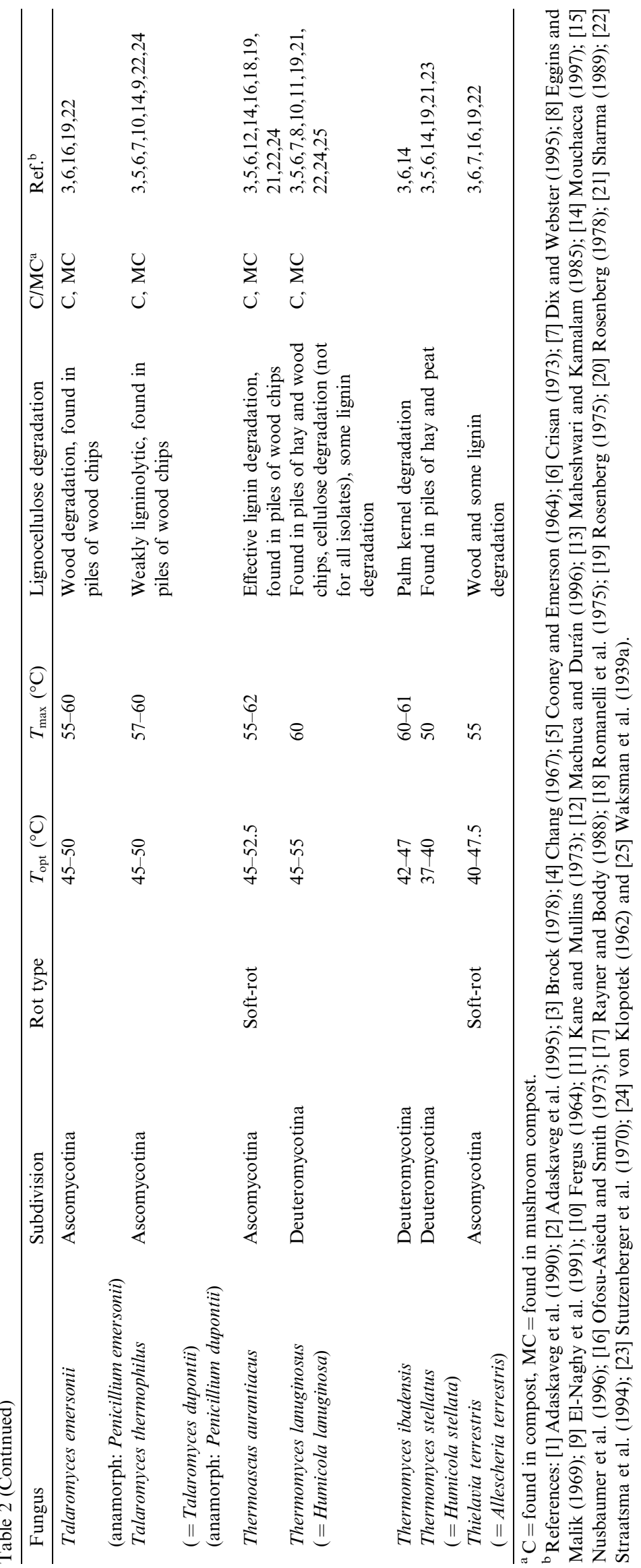


cellulose, and solubilize lignin, and they tolerate higher temperatures and $\mathrm{pH}$ than fungi. Thus, actinomycetes are important agents of lignocellulose degradation during peak heating, although their ability to degrade cellulose and lignin is not as high as that of fungi (Crawford, 1983; Godden et al., 1992). Under adverse conditions actinomycetes survive as spores (Cross, 1968).

\subsection{Fungi}

Temperature is one of the most important factors affecting fungal growth. Other important factors are sources of carbon and nitrogen, and the $\mathrm{pH}$. A moderately high level of nitrogen is needed for fungal growth although some fungi, mainly wood-rotting fungi, grow at low nitrogen levels. Indeed, a low nutrient nitrogen level is often a prerequisite for lignin degradation (Eriksson et al., 1990; Dix and Webster, 1995). However, low nutrient nitrogen is a rate-limiting factor for the degradation of cellulose (Dix and Webster, 1995). Most fungi prefer an acidic environment but tolerate a wide range of $\mathrm{pH}$, with the exception of the Basidiomycotina which do not grow well above $\mathrm{pH}$ 7.5. Coprinus species are the only Basidiomycotina which prefer an alkaline environment (Dix and Webster, 1995).

The majority of fungi are mesophiles which grow between $5^{\circ} \mathrm{C}$ and $37^{\circ} \mathrm{C}$, with an optimum temperature of $25-30^{\circ} \mathrm{C}$ (Dix and Webster, 1995). However, in the compost environment the elevated temperature means that the small group of thermophilic fungi is an important biodegradation agent. In nature, thermophilic fungi grow in garden compost heaps, bird nests, coal tips, power plant cooling pipes and effluents, in the storage of many agricultural products (like hay, grain etc.) and in piles of wood chips and peat (Sharma, 1989; Dix and Webster, 1995). In mushroom compost, thermophilic fungi are responsible for the degradation of lignocellulose, which is a prerequisite for the growth of the edible fungus (Sharma, 1989).

Cooney and Emerson (1964) define thermophilic fungi as fungi with a maximum growth temperature of $50^{\circ} \mathrm{C}$ or higher and a minimum growth temperature of $20^{\circ} \mathrm{C}$ or higher. Thermotolerant species have a maximum growth temperature of about $50^{\circ} \mathrm{C}$ and a minimum well below $20^{\circ} \mathrm{C}$ (Cooney and Emerson, 1964). Crisan (1973), however, defines thermophilic fungi as fungi with a temperature optimum of $40^{\circ} \mathrm{C}$ or higher. Thermophilic and thermotolerant fungi which are known to have cellulolytic or ligninolytic activity, or which have been found growing in lignocellulose substrate or compost, are listed in Table 2.

Cooney and Emerson (1964), Crisan (1973), Rosenberg (1975), Brock (1978) and Mouchacca (1997) have enumerated several species and varieties of thermophilic fungi. The growth temperature optimum for most thermophilic fungi is between $40^{\circ} \mathrm{C}$ and $50^{\circ} \mathrm{C}$ and the maximum is $55^{\circ} \mathrm{C}$ (See Table 2). According to Cooney and Emerson $(1964), 60^{\circ} \mathrm{C}$ is the temperature limit of fungi and, according to Brock (1978), $60-61.5^{\circ} \mathrm{C}$ is the temperature limit for all eukaryotes. Temperature tolerance varies within the genera and even between the isolates of fungal species. The substrate may also have some influence on the temperature tolerance (OfosuAsiedu and Smith, 1973). There are indeed some reports of fungal growth above $61.5^{\circ} \mathrm{C}$. El-Naghy et al. (1991) reported saccharification activity of Sporotrichum thermophile (syn. Myceliophthora thermophile) at $65^{\circ} \mathrm{C}$, and Ofosu-Asiedu and Smith (1973) found Talaromyces emersonii still to be very active after four weeks at $60^{\circ} \mathrm{C}$ indicating that the fungus might be active at even higher temperatures. However, the growth of the fungus near the temperature maximum is very slow compared to that at the optimum temperature (Rosenberg, 1975).

The ligninolytic capacity of all thermophilic fungi is not known (Table 2). However, most of them are known to be able to degrade wood or other lignocellulose, cellulose or hemicelluloses (e.g. Fergus, 1969; OfosuAsiedu and Smith, 1973; Sharma, 1989; Kuhad et al., 1997). The ability of fungi to hydrolyse hemicelluloses is probably more common than cellulose hydrolyzation (Dix and Webster, 1995).

The most effective lignin degraders are Basidiomycotina, but according to Cooney and Emerson (1964) and Mouchacca (1997) all Basidiomycotina are mesophilic. However, a few Basidiomycotina grow well at elevated temperatures. Phanerochaete chrysosporium (anamorph Sporotrichum pulverulentum) is a white-rot fungus with an optimum temperature of $36-40^{\circ} \mathrm{C}$ and maximum temperature $46-49^{\circ} \mathrm{C}$ (Mouchacca, 1997). Ganoderma colossum is another white-rot fungus which is still capable of growing at $45^{\circ} \mathrm{C}$ and has an optimum temperature of $40^{\circ} \mathrm{C}$ (Adaskaveg et al., 1990; 1995). In the genus Coprinus there are some species that have an optimum temperature of above $40^{\circ} \mathrm{C}$ (Crisan, 1973). Some of the wood-rotting Coprinus species are brownrot fungi which modify rather than degrade lignin (Rayner and Boddy, 1988).

A thermophilic Ascomycotina, Thermoascus aurantiacus, has a high ligninolytic capacity (Machuca et al., 1995), and it has been isolated from compost (von Klopotek, 1962). Heat-tolerant soft-rot fungi, such as Thielavia terrestris, Paecilomyces sp. and Talaromyces thermophilus, are weakly ligninolytic (Dix and Webster, 1995).

Nusbaumer et al. (1996), Thambirajah and Kuthubutheen (1989), Thambirajah et al. (1995), von Klopotek (1962) and Waksman et al. (1939a,b) have studied the occurrence of fungi during composting. Waksman et al. (1939a,b) studied composting on a laboratory scale at temperatures of $28^{\circ} \mathrm{C}, 50^{\circ} \mathrm{C}, 65^{\circ} \mathrm{C}$ and $75^{\circ} \mathrm{C}$. At $28^{\circ} \mathrm{C}$ the population was heterogeneous with bacteria being 
dominant throughout the whole period, and fungi appearing later. Fungi, together with bacteria and actinomycetes, formed the microbial population in the compost at $50^{\circ} \mathrm{C}$. At the beginning there were active thermophilic fungi, which were followed by bacteria and actinomycetes, some of them growing on the fungal mycelium. The composts used in the other studies mentioned above were full scale.

The raw material of compost contains about $10^{6} \mathrm{mi}-$ crobial counts of mesophilic fungi/g of raw material and thermophilic fungi $10^{3}-10^{6} / \mathrm{g}$ (von Klopotek, 1962; Thambirajah and Kuthubutheen, 1989; Thambirajah et al., 1995). The predominant mesophilic fungus in the raw material has been Geotrichum sp. (von Klopotek, 1962; Nusbaumer et al., 1996) and the thermotolerant fungus Aspergillus fumigatus (von Klopotek, 1962). Counts of fungi decrease as the temperature rises, and at $64^{\circ} \mathrm{C}$ all the thermophilic fungi disappear. However, a mesophilic fungus, Cladosporium cladosporioides, grew well at 64 $65^{\circ} \mathrm{C}$, but no fungi were detected at $67^{\circ} \mathrm{C}$ (von Klopotek, 1962). In the studies of Thambirajah et al. (1995) and Waksman et al. (1939a,b), no fungi were detected when the temperature was over $60^{\circ} \mathrm{C}$. In the study of Thambirajah and Kuthubutheen (1989) fungi survived at high temperature probably due to the short duration of peak heating. When the temperature decreases below $60^{\circ} \mathrm{C}$ mesophilic and thermophilic fungi reappear in compost (von Klopotek, 1962; Thambirajah et al., 1995). The dominating fungus after peak heating is Aspergillus sp. (Nusbaumer et al., 1996) or Thermomyces lanuginosus (von Klopotek, 1962), which was also found to dominate at $50^{\circ} \mathrm{C}$. T. lanuginosus can decompose cellulose, hemicelluloses and even lignin, although to a much smaller extent than the other components (Waksman et al., 1939a,b). In the studies of Thambirajah and Kuthubutheen (1989) and Thambirajah et al. (1995) the number of mesophilic and thermophilic fungi $\left(10^{4}-10^{6} / \mathrm{g}\right)$ in mature compost were the same, but in the study of von Klopotek (1962) thermophilic fungi dominated especially in the drier parts of mature compost.

Coprinus sp. (von Klopotek, 1962; Nussbaumer et al., 1996), Panaeolus sp., Corticium coronilla and possibly
Mycena sp. (von Klopotek, 1962) are Basidiomycotina occurring in compost. They were all isolated from compost during the cooling and maturation phase or from mature compost (von Klopotek, 1962; Nussbaumer et al., 1996).

\section{Biodegradation of lignin}

\subsection{Lignin-degrading fungi}

Lignin degraders in nature are mainly white-rot fungi (Table 3). There are several thousand species of whiterot fungi, most of them Basidiomycotina, in addition to a few Ascomycotina which can cause white-rot (Eriksson et al., 1990). White-rot fungi belonging to the subdivision Basidiomycotina attack either hardwood or softwood, while Ascomycotina probably degrade only hardwood (Kirk and Farrell, 1987). Lignin degradation by white-rot fungi is faster than that of any other organisms and they are responsible for most of the lignin decomposition in nature. However, the growth substrate is not only lignin, but also hemicelluloses and cellulose (Buswell and Odier, 1987; Kirk and Farrell, 1987; Blanchette, 1995). The growth of fungi decreases in nitrogen- or carbon-depleted conditions and ligninolytic activity appears as a form of secondary metabolism (Brown, 1985; Kirk and Farrell, 1987).

White-rot fungi can cause selective or nonselective delignification of wood. In selective delignification, lignin is removed without any marked loss of cellulose, and in nonselective delignification all the major cell wall components are degraded (Eriksson et al., 1990; Blanchette, 1995). Although some white-rot fungi always attack wood either in a selective or in nonselective way, there are fungi which are capable of both forms of degradation, e.g. Heterobasidion annosum (Eriksson et al., 1990; Blanchette, 1995). Among the best studied white-rot fungi are Phanerochaete chrysosporium and Phlebia radiata, which degrade lignin selectively, and Trametes versicolor which degrades lignin nonselectively (Hatakka, 1994).

Table 3

Lignin-degrading organisms (Buswell and Odier, 1987; Rayner and Boddy, 1988; Eriksson et al., 1990; Blanchette, 1995)

\begin{tabular}{|c|c|c|c|c|}
\hline Organism & Subdivision & Lignin degradation & Environment & Genera (e.g.) \\
\hline White-rot fungi & $\begin{array}{l}\text { Basidiomycotina } \\
\text { (Ascomycotina) }\end{array}$ & $\begin{array}{l}\text { Lignin mineralization, } \\
\text { selective or nonselective } \\
\text { delignification }\end{array}$ & Mainly hardwood & $\begin{array}{l}\text { Phanerochaete, Phlebia, } \\
\text { Trametes }\end{array}$ \\
\hline Brown-rot fungi & Basidiomycotina & Lignin modification & Mainly softwood & Poria, Polyporus \\
\hline Soft-rot fungi & $\begin{array}{l}\text { Ascomycotina or } \\
\text { Deuteromycotina }\end{array}$ & Limited lignin degradation & $\begin{array}{l}\text { Aquatic environment, wood } \\
\text { with preserving chemicals, } \\
\text { plant litter }\end{array}$ & $\begin{array}{l}\text { Chaetomium, } \\
\text { Paecilomyces, Fusarium }\end{array}$ \\
\hline Bacteria & $\begin{array}{l}\text { Actinomycetes or } \\
\text { Myxobacteria }\end{array}$ & Limited lignin degradation & $\begin{array}{l}\text { Sapwood, water-saturated } \\
\text { wood, wood at late stage of } \\
\text { decomposition, plant litter }\end{array}$ & $\begin{array}{l}\text { Streptomyces, Nocardia, } \\
\text { Pseudomonas }\end{array}$ \\
\hline
\end{tabular}


White-rot fungi degrade lignin by means of oxidative enzymes (Hatakka, 1994). Because of the nature and size of the lignin molecule, the enzymes responsible for the initial attack must be extracellular and nonspecific (Kirk and Farrell, 1987; Hatakka, 1994). The best studied extracellular enzymes of white-rot fungi are lignin peroxidases (LiPs), manganese peroxidases (MnPs) and laccase. The role of $\mathrm{LiP}$ and $\mathrm{MnP}$ in lignin degradation has been verified, while that of other enzymes is still uncertain (Hatakka, 1994). Different white-rot fungi produce different combinations of enzymes: there are fungi producing $\mathrm{LiP}$ and $\mathrm{MnP}$, fungi producing $\mathrm{MnP}$ and laccase, fungi producing LiP and laccase and fungi which produce neither $\mathrm{LiP}$ nor $\mathrm{MnP}$, but laccase and aryl alcohol oxidase (AAO) or some other enzyme (Hatakka 1994). P. chrysosporium, $P$. radiata and $T$. versicolor belong to the $\mathrm{LiP}-\mathrm{MnP}$ group. Usually the members of this group also produce laccase, but $P$. chrysosporium is an exception, although very recently laccase production by this fungus has been reported under specific conditions (Srinivasan et al., 1995). Several fungi belonging to the $\mathrm{LiP}-\mathrm{MnP}$ and the $\mathrm{MnP}-$ laccase groups are effective lignin degraders, while the lignin degradation capability of fungi belonging to the LiP-laccase group is much lower (Hatakka, 1994). This may be due to the essential role of $\mathrm{MnP}$ in lignin degradation. However, lignin degradation is a complex process and the enzymes have probably synergistic effects on each other. The mineralization of ${ }^{14} \mathrm{C}$-lignin in optimal conditions by the most effective white-rot fungi can reach $50 \%$ or even $70 \%$. In an experiment with several strains of $P$. chrysosporium $45-50 \%$ of $\beta-{ }^{14} \mathrm{C}$ DHP was mineralized and $69 \%$ of the ${ }^{14} \mathrm{C}$-lignin from fir by one of the strains in 22 days (Hatakka et al., 1984).

Brown-rot fungi extensively degrade cellulose and hemicelluloses in wood, but lignin degradation is limited. Lignin is chemically modified by demethylation of its phenolic and nonphenolic units (Kirk and Farrell, 1987; Eriksson et al., 1990), and limited aromatic hydroxylation and ring cleavage of lignin also occurs (Kirk and Farrell, 1987). Brown-rot fungi are able to mineralize the methoxyl groups of lignin, but the mineralization of other parts is much lower (Buswell and Odier, 1987; Kirk and Farrell, 1987). Brown-rot fungi mainly colonize softwoods and only $6 \%$ of all wood-rotting Basidiomycotina are brown-rotters (Rayner and Boddy, 1988). Brown-rotted wood is brown in colour, consisting of a high proportion of modified lignin residue and little carbohydrates, and it persists in the forest for a long time (Blanchette, 1995).

Soft-rot fungi are Ascomycotina or Deuteromycotina which degrade both hardwood and softwood, although hardwoods are degraded to a greater extent than softwoods (Kuhad et al., 1997). All wood components are degraded, but the rate of degradation is minimal compared to that of white-rot or brown-rot fungi (Eriksson et al., 1990). Soft-rot fungi degrade wood in environments that are too severe for white- or brown-rot fungi, generally in wet environments (Blanchette, 1995). They also decompose plant litter in soils. Haider and Trojanowski (1980) and Rodriguez et al. (1996) studied the lignin mineralization capacity of soft-rot fungi. In 35 days, Chaetomium piluliferum mineralized $17 \%$ of ring${ }^{14} \mathrm{C}$-labelled corn stalk lignin, but the amount mineralized by other soft-rot fungi was much less (Haider and Trojanowski, 1980). Mineralization of side chain-and methoxy-labelled lignins by all fungi was slightly higher (Haider and Trojanowski, 1980). The soil fungi Penicillium chrysogenum, Fusarium solani and Fusarium oxysporum mineralized $20-27 \%$ of ${ }^{14} \mathrm{C}-\mathrm{MWL}$ from wheat straw in 28 days. P. chrysogenum can also attack kraft and organosolv lignins (Rodriguez et al., 1996). Little is known about the enzyme system of soft-rot fungi or their lignin degradation capacity as litter decomposing organisms (Haider and Trojanowski, 1980; Kirk and Farrell, 1987). Lignin-related compounds, like vanillic acid and phenols, are rapidly degraded by softrot fungi (Haider and Trojanowski, 1980). This could mean that soft-rot fungi are an important group of lignin degraders in mixed populations, although their lignin degradation capacity alone is limited.

\subsection{Lignin-degrading bacteria}

There are many genera of actinomycetes and eubacteria which can degrade extracted lignin and DHP (Buswell and Odier, 1987). Many bacterial strains, especially actinomycetes, can solubilize and modify the lignin structure extensively, but their ability to mineralize lignin is limited (Buswell and Odier, 1987; Ball et al., 1989; Eriksson et al., 1990; Godden et al., 1992). Actinomycetes degrade lignin as their primary metabolic activity and at high nitrogen levels compared to whiterot fungi, most of which degrade lignin via their secondary metabolism. Some species of Streptomyces and Nocardia have been shown to degrade some lignin in soil (Haider and Trojanowski, 1980). Streptomyces badius mineralizes $3.2 \%$ of ${ }^{14} \mathrm{C}-\mathrm{MWL}$ in 30 days, and mineralization was further enhanced to $11 \%$ when cellulose and yeast extract were added to the medium (Eriksson et al., 1990). There is some evidence that the grass lignins are attacked by actinomycetes more efficiently than the wood lignins (Buswell and Odier, 1987).

The lignin-degrading eubacteria can be divided into erosion, cavitation and tunnelling bacteria (Eriksson et al., 1990; Blanchette, 1995). Wood is degraded by bacteria under certain extreme environmental conditions, e.g. wood saturated with water, almost anaerobic conditions or wood with a high extractive content. However, the rate of degradation is very slow (Eriksson et al., 1990; Blanchette, 1995). Erosion bacteria grow towards the middle lamella of the wood cells and cause 
erosion of the fibre wall, while tunnelling bacteria grow within the cell wall. The species of the tunnelling bacteria have not been identified (Eriksson et al., 1990). Bacteria of several genera such as Pseudomonas, Alcaligenes, Arthrobacter, Nocardia and Streptomyces can degrade single-ring aromatic compounds. The role of bacteria may be significant in consuming the small molecular weight intermediate compounds produced by fungi (Vicuña, 1988; Rüttimann et al., 1991).

Although aerobic microorganisms are primarily lignin degraders in most environments, it has been shown that anaerobic rumen microorganisms are cabable of degrading plant fibre cell walls (Kuhad et al., 1997). Colberg (1988) has reviewed the anaerobic microbial degradation of lignin compounds and concluded that the intermediate metabolic products called oligolignols, released during aerobic degradation, may be partially degraded to $\mathrm{CO}_{2}$ and $\mathrm{CH}_{4}$ by anaerobic microorganisms. Also, polymeric lignin is mineralized in anoxic sediments at a slow rate. In many studies, however, no anaerobic degradation of lignin has been observed (e.g. Hackett et al., 1977; Micales and Skog, 1997). Benner and Hodson (1985) reported that an elevated temperature of $55^{\circ} \mathrm{C}$ enhances the anaerobic degradation of lignin, nevertheless mineralization of DHP stays low. Chandler et al. (1980) have formulated an equation for the anaerobic degradation of different organic materials. Degradation is directly proportional to the lignin content of the material:

$B=0.830-0.028 X$,

where $B$ is biodegradable fraction and $X$ is the lignin content, $\%$ of the volatile solids. The data were collected from the anaerobic fermentation process using a wide range of lignocellulosic materials (Chandler et al., 1980).

\subsection{Studies in the compost environment}

Stutzenberger et al. (1970) studied the composting of municipal solid waste containing paper products for 49 days. Lignin may have inhibited the degradation of cellulose, because $40 \%$ of the cellulose remained undegraded. The cellulose content of the waste was $46-56 \%$ but degradation of lignin was not determined (Stutzenberger et al., 1970). Micales and Skog (1997) reported that lignin also inhibits the anaerobic degradation of cellulose in landfills.

Lignin degradation of plant residues has been studied in the composting experiments summarized in Tables 4 and 5. Mineralization of lignin in the compost environment was not studied in any of the experiments. However, Hackett et al. (1977), Haider et al. (1977) and Martin and Haider (1980) studied lignin mineralization by a mixed population of microorganisms in soil. According to Haider et al. (1977), soil microbes could mineralize $27 \%$ of the ring- ${ }^{14} \mathrm{C}$-corn stalk lignin and $21 \%$ of the ring- ${ }^{14} \mathrm{C}$-DHP, while $54 \%$ and $61 \%$ of the ${ }^{14} \mathrm{C}$-label, respectively, was found in humic substances after 28 weeks of incubation. Hackett et al. (1977) studied the lignin mineralization capacity of 30 different soil samples from five different sites. Mineralization of ring- ${ }^{14} \mathrm{C}$-DHP varied from $3.1 \%$ to $42.4 \%$ in 41 days. The highest mineralization was achieved in soil from a geyser basin at its natural temperature of $35^{\circ} \mathrm{C}$ (Hackett et al., 1977).

The effect of temperature on lignin degradation has been studied in a few composting experiments (Table 5). Horwath and Elliott (1996) composted ryegrass for 45 days at a mesophilic temperature of $25^{\circ} \mathrm{C}$, as well as in a temperature profile in which the temperature was either $25^{\circ} \mathrm{C}$ or $50^{\circ} \mathrm{C}$. The proportion of lignin degraded, as determined by the Klason method, was $7 \%$ and $27 \%$, respectively. At both temperatures the elemental ratio of the residual Klason lignin changed, and it was estimated that only $6 \%$ of the residual Klason lignin was unaltered after composting (Horwath and Elliott, 1996).

Waksman et al. (1939b) studied the degradation of lignin in composts at different temperatures (Fig. 4). The highest degradation of lignin occurred at $50^{\circ} \mathrm{C}$, while degradation was to some extent lower at $28^{\circ}$ and $65^{\circ} \mathrm{C}$. At $75^{\circ} \mathrm{C}$ no biodegradation of lignin occurred, but $12 \%$ of the lignin was solubilized as a result of the high

Table 4

Studies in which lignin degradation during composting or in soil incubation has not been reported

\begin{tabular}{|c|c|c|c|c|c|c|}
\hline Waste & Time/d & Compost/Soil & $\begin{array}{l}\text { Original lignin- } \\
\text { content } / \%\end{array}$ & Note & $\begin{array}{l}\text { Lignin analysis } \\
\text { method }\end{array}$ & Ref. \\
\hline Grape pulp & 12 & Compost, 701 & 39.4 & $\begin{array}{l}\text { Thermophilic phase } \\
3 \mathrm{~d}\end{array}$ & Acid detergent? & $\begin{array}{l}\text { Faure and Des- } \\
\text { champs (1990) }\end{array}$ \\
\hline $\begin{array}{l}\text { Grass, leaf, corn } \\
\text { cob }\end{array}$ & 14 & $\begin{array}{l}\text { Compost, bench } \\
\text { scale }\end{array}$ & 12.4 & $\begin{array}{l}\text { Fixed temperature of } \\
50^{\circ} \mathrm{C}\end{array}$ & $\begin{array}{l}\text { Acetyl bromide } \\
\text { (and FTIR) }\end{array}$ & $\begin{array}{l}\text { Tseng et al. } \\
(1996)\end{array}$ \\
\hline Cotton & 90 & Compost, 1501 & 14.2 & $\begin{array}{l}\text { Thermophilic phase } \\
\text { about } 7 \mathrm{~d}\end{array}$ & Acid detergent? & Baca et al. (1992) \\
\hline $\begin{array}{l}\text { Wheat } \\
\text { internodes }\end{array}$ & 224 & $\begin{array}{l}\text { Soil (sample in } \\
\text { bags) }\end{array}$ & 9.4 & Buried & $\mathrm{H}_{2} \mathrm{SO}_{4}$ & $\begin{array}{l}\text { Robinson et al. } \\
\text { (1994) }\end{array}$ \\
\hline $\begin{array}{l}\text { Market waste, } \\
\text { hay, fresh wood }\end{array}$ & 295 & Compost, 7851 & 25.1 & $\begin{array}{l}\text { Thermophilic phase } \\
8 \mathrm{~d} \text {, frozen for } 54 \text { days }\end{array}$ & Klason lignin & $\begin{array}{l}\text { Nusbaumer } \\
\text { et al. (1996) }\end{array}$ \\
\hline
\end{tabular}


Table 5

Studies in which lignin degradation during composting or in soil has been reported

\begin{tabular}{|c|c|c|c|c|c|c|c|}
\hline Waste & Time/d & Compost/soil & $\begin{array}{l}\text { Original lignin- } \\
\text { content } / \%\end{array}$ & $\begin{array}{l}\text { Degraded } \\
\text { lignin/ } \%\end{array}$ & Note & $\begin{array}{l}\text { Analyzig method } \\
\text { of lignin }\end{array}$ & Ref. \\
\hline \multirow[t]{2}{*}{ Ryegrass straw } & 45 & $\begin{array}{l}\text { Compost, } \\
140 \mathrm{ml}\end{array}$ & 12.15 & 7 & $25^{\circ} \mathrm{C}$ & $\begin{array}{l}\text { Modified } \\
\text { Klason lignin }\end{array}$ & $\begin{array}{l}\text { Horwath and } \\
\text { Elliott (1996) }\end{array}$ \\
\hline & & & & 27 & $\begin{array}{l}30 \mathrm{~d} 50^{\circ} \mathrm{C} \\
15 \mathrm{~d} 25^{\circ} \mathrm{C}\end{array}$ & & \\
\hline \multirow{4}{*}{$\begin{array}{l}\text { Horse } \\
\text { manure, wheat } \\
\text { straw }\end{array}$} & 47 & Compost, $600 \mathrm{~g}$ & 20.5 & 26 & $28^{\circ} \mathrm{C}$ & - & $\begin{array}{l}\text { Waksman } \\
\text { et al. (1939b) }\end{array}$ \\
\hline & & & & 43 & $50^{\circ} \mathrm{C}$ & & \\
\hline & & & & 33 & $65^{\circ} \mathrm{C}$ & & \\
\hline & & & & 12 & $75^{\circ} \mathrm{C}$ & & \\
\hline $\begin{array}{l}\text { Olive mill waste } \\
\text { water, wheat } \\
\text { straw }\end{array}$ & 140 & Compost, pile & - & 70 & $\begin{array}{l}\text { Prolonged } \\
\text { thermophilic } \\
\text { phase of } 35 \mathrm{~d}\end{array}$ & $\begin{array}{l}\text { Modified } \\
\text { Klason lignin }\end{array}$ & $\begin{array}{l}\text { Tomati et al. } \\
\text { (1995) }\end{array}$ \\
\hline $\begin{array}{l}\text { Canola residue } \\
\text { (Brassica } \\
\text { campestris) }\end{array}$ & 154 & $\begin{array}{l}\text { Soil (sample in } \\
\text { bags) }\end{array}$ & 11.5 & $\begin{array}{l}17 \\
17\end{array}$ & $\begin{array}{l}\text { Buried Not } \\
\text { buried }\end{array}$ & Acid detergent & $\begin{array}{l}\text { Franzluebbers } \\
\text { et al. (1996) }\end{array}$ \\
\hline Wheat leaves & 224 & $\begin{array}{l}\text { Soil (sample in } \\
\text { bags) }\end{array}$ & 5.92 & 99.2 & Buried & $\mathrm{H}_{2} \mathrm{SO}_{4}$ & $\begin{array}{l}\text { Robinson } \\
\text { et al. (1994) }\end{array}$ \\
\hline
\end{tabular}

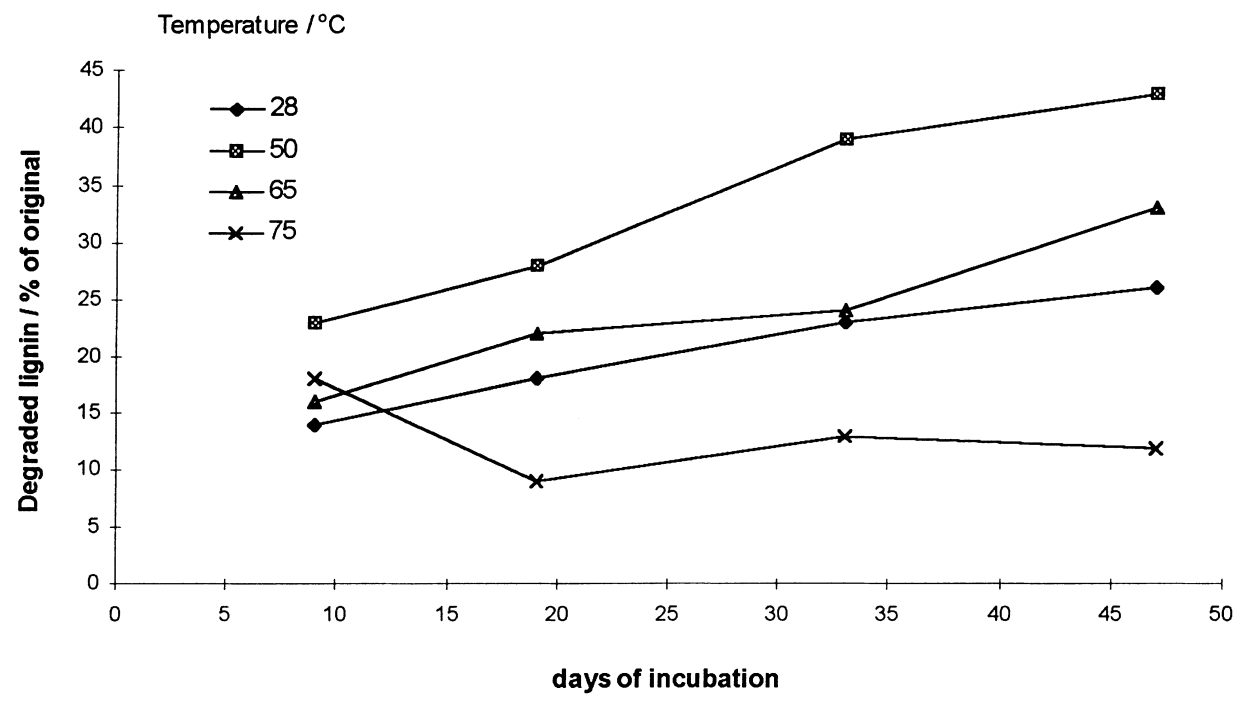

Fig. 4. Lignin degradation in horse manure and straw compost. Original lignin content $20.5 \%$. The data of the figure are derived from Waksman et al. (1939b).

temperature and alkaline reaction of the compost (Waksman et al., 1939b).

In experiments where the thermophilic phase lasted for a short time, between 7 and 14 days, lignin was not degraded (Table 4), not even when the total composting time was as long as 295 days (Nusbaumer et al., 1996). According to a study by Tomati et al. (1995), 70\% of lignin was degraded during 35 days when the temperature of the compost was kept at $50^{\circ} \mathrm{C}$, whereas only negligible degradation occurred later during compost maturation. According to these studies, it seems probable that sufficient duration of the thermophilic phase is an important factor for lignin degradation in the com- post environment. However, the degradation of lignin in agricultural residues in soil has been reported in some studies (Robinson et al., 1994; Franzluebbers et al., 1996). The original lignin content and thickness of the material has an influence on lignin degradation. When buried in soil for 224 days the lignin of wheat leaves was almost totally degraded, while the lignin of wheat internodes did not degrade at all. The leaves contained $5.92 \%$ lignin and the internodes 9.2\% lignin (Robinson et al., 1994).

Waksman et al. (1939a) studied the degradation capacity of some microorganisms isolated from compost. Two thermophilic actinomycete isolates degraded 
$0.7-2.5 \%$ of the lignin in 42 days at $50^{\circ} \mathrm{C}$, the thermophilic fungus Thermomyces lanuginosus $4.2 \%$, but neither of the two bacteria studied were capable of lignin degradation alone. However, the natural microbial population in manure degraded $11.5 \%$ of the lignin. The natural population also decomposed $62 \%$ of the total dry material as compared to $40 \%$ for the fungus (Waksman et al., 1939a).

\section{Conclusions}

This literature survey shows that very little is known about the degradation of lignin in compost. Although it would appear that lignin can be degraded or transformed extensively during composting, the lignin loss in a compost environment is hardly due to extensive mineralization of lignin. The organisms most efficient at mineralizing lignin, white-rot fungi, do not survive the thermophilic phase of composting, and thus cannot play any significant role in lignin degradation. The basidiomycetous fungi that have been found in composts appear during the cooling and maturation phase or in mature compost (von Klopotek, 1962; Nusbaumer et al., 1996). The other microorganisms in compost, mainly thermophilic microfungi, are probably the most important lignin degraders (Waksman et al., 1939a,b) and synergistic effects with other organisms enhance the degradation significantly (Waksman et al., 1939a). The mineralization of lignin by compost microorganisms is probably of the same order of magnitude as that by a mixed population of soil microorganisms, and the degraded lignin fragments are building units for humic substances both in soil (Hackett et al., 1977; Haider et al., 1977; Martin and Haider, 1980) and in compost (Horwath and Elliott, 1996). Lignin degradation in composts is regulated by temperature, the original lignin content and the thickness of the material.

\section{References}

Adaskaveg, J.E., Gilbertson, R.L., Blanchette, R.A., 1990. Comparative studies of delignification caused by Ganoderma species. Appl. Environ. Microbiol. 56, 1932-1943.

Adaskaveg, J.E., Gilbertson, R.L., Dunlap, M.R., 1995. Effects of incubation time and temperature on in vitro selective delignification of silver leaf oak by Ganoderma colossum. Appl. Environ. Microbiol. 61, 138-144.

Aiken, G.R., McKnight, D.M., Wershaw, R.L., MacCarthy, P., 1985 An introduction to humic substances in soil, sediment, and water. In: Aiken, G.R., McKnight, D.M., Wershaw, R.L., MacCarthy, P. (Eds.), Humic Substances in Soil, Sediment, and Water: Geochemistry, Isolation, and Characterization, 1-9. Wiley, USA.

Albertsson, A.C., Karlsson, S., 1995. Degradable polymers for the future. Acta Polymer 46, 114-123.

Almendros, G., Gonzalez-Vila, F.J., Martin, F., Fründ, R., Lüdemann, H.D., 1992. Solid state NMR studies of fire-induced changes in the structure of humic substances. Sci. Total Environ. 117/118, 63-74.
Argyropoulos, D.S., Menachem, S.B., 1997. Lignin. In: Eriksson, K.-E.L. (Ed.), Advances in Biochemical Engineering Biotechnology, vol. 57. Springer, Germany, pp. 127-158.

Atkinson, C.F., Jones, D.D., Gauthier, J.J., 1996a. Biodegradabilities and microbial activities during composting of oxidation ditch sludge. Compost. Sci. Utiliz. 4, 84-96.

Atkinson, C.F., Jones, D.D., Gauthier, J.J., 1996b. Putative anaerobic activity in aerated composts. J. Ind. Microbiol. 16, 182-188.

Baca, M.T., Fornasier, F., de Nobili, M., 1992. Mineralization and humification pathways in two composting processes applied to cotton wastes. J. Ferment. Bioeng. 74, 179-184.

Ball, A.S., Betts, W.B., McCarthy, A.J., 1989. Degradation of ligninrelated compounds by actinomycetes. Appl. Environ. Microbiol. $55,1642-1644$

Beffa, T., Blanc, M., Lyon, P.F., Vogt, G., Marchiani, M., Fischer, J.L., Aragano, M., 1996. Isolation of Thermus strains from hot composts $60-80^{\circ} \mathrm{C}$. Appl. Environ. Microbiol. 62, 1723-1727.

Benner, R., Hodson, R.E., 1985. Thermophilic anaerobic biodegradation of $\left[{ }^{14} \mathrm{C}\right]$ ignin, $\left[{ }^{14} \mathrm{C}\right]$ cellulose, and $\left[{ }^{14} \mathrm{C}\right]$ lignocellulose preparations. Appl. Environ. Microbiol. 50, 971-976.

Biermann, C.J., 1993. Essentials of Pulping and Papermaking. Academic Press, USA.

Blanchette, R.A., 1995. Degradation of lignocellulose complex in wood. Can. J. Bot. 73, S999-S1010.

Brock, T.D., 1978. Thermophilic Microorganisms and Life at High Temperatures. Springer, USA.

Brown, A., 1985. Review of lignin in biomass. J. Appl. Biochem. 7, 371-387.

Buswell, J.A., Odier, E., 1987. Lignin biodegradation. CRC Crit. Rev. Biotechnol. 6, 1-60.

Chandler, J.A., Jewell, W.J., Gossett, J.M., Soest, P.J., Robertson, J.B., 1980. Predicting methane fermentation biodegradability. Biotechnology and Bioengineering Symposium 10, 93-107.

Chang, Y., 1967. The fungi of wheat straw compost. II Biochemical and physiological studies.. Trans. Br. Mycol. Soc. 50, 667-677.

Chen, Y., Chefetz, B., Hadar, Y., 1996. Formation and properties of humic substance originating from compost. In: Bertoldi, M., Sequi, P., Lemmes, B., Papi, T. (Eds.), European Commission International Symposium. The Science of Composting, 382-393. Blackie Academic \& Professional, England.

Colberg, P.J., 1988. Anaerobic microbial degradation of cellulose, lignin, oligolignols, and monoaromatic lignin derivates. In: Zehnder, A.J.B. (Ed.), Biology of Anaerobic Microorganisms, 333-372. Wiley, USA.

Cooney, D.G., Emerson, R., 1964. Thermophilic Fungi. W.H. Freeman, USA.

Crawford, D.L., Crawford, R.L., 1980. Microbial degradation of lignin. Enzyme Microb. Technol. 2, 11-22.

Crawford, R.L., Robinson, L.E., Cheh, A.M., 1980. ${ }^{14}$ C-labeled lignins as substrates for the study of lignin biodegradation and transformation. In: Kirk, T.K., Higuchi, T., Chang, H.m. (Eds.), Lignin Biodegradation: Microbiology Chemistry and Applications. CRC Press, USA, pp. 61-76.

Crawford, J.H., 1983. Composting of agricultural wastes - a review. Process Biochem. 18, 14-18.

Crisan, E.V., 1973. Current concepts of thermophilism and the thermophilic fungi. Mycologia 65, 1171-1198.

Cross, T., 1968. Thermophilic actinomycetes. J. Appl. Bact. 31, $36-53$.

Dence, C.W., 1992. The determination of lignin. In: Lin, S.Y., Dence, C.W. (Eds.), Methods in Lignin Chemistry, 33-61. Springer, Berlin.

Dix, N.J., Webster, J., 1995. Fungal Ecology. Chapman \& Hall, Cambridge, Great Britain.

Eggins, H.O.W., Malik, K.A., 1969. The occurrence of thermophilic cellulolytic fungi in a pasture land soil. Antonie v. Leeuwenhoek $35,178-184$. 
El-Naghy, M.A., El-Katatny, M.S., Attia, A.A., 1991. Degradation of cellulosic materials by Sporotrichum thermophile culture filtrate for sugar production. Int. Biodeter. 27, 75-86.

Eriksson, K.-E.L., Blanchette, R.A., Ander, P., 1990. Microbial and Enzymatic Degradation of Wood and Wood Components. Springer, Berlin, Germany.

European Standard CEN TC261, SC4, WG2, draft 1998. Requirements for packaging recoverable in the form of composting and biodegradation. Test scheme and evaluation criteria for the final acceptance of packaging.

European Union Packaging and Packaging Waste Directive, 1994. European parliament and council directive 94/62/EC of 20 December 1994 on packaging and packaging waste.

Faure, D., Deschamps, A.M., 1990. Physico-chemical and microbiological aspects in composting of grape pulps. Biol. Wastes 34, 251258.

Fergus, C.L., 1964. Thermophilic and thermotolerant molds and actinomycetes of mushroom compost during peak heating. Mycologia 56, 267-284.

Fergus, C.L., 1969. The cellulolytic activity of thermophilic fungi and actinomycetes. Mycologia 61, 120-129.

Forssell, P., Mikkilä, J., Suortti, T., Seppälä, J., Poutanen, K., 1996. Plasticization of barley starch with glycerol and water. J. Macromol. Pure Appl. Chem. A33, 703-715.

Franzluebbers, A.J., Arshad, M.A., Ripmeester, J.A., 1996. Alterations in canola residue composition during decomposition. Soil Biol. Biochem. 28, 1289-1295.

Fustec, E., Chauvet, E., Gas, G., 1989. Lignin degradation and humus formation in alluvial soils and sediments. Appl. Environ. Microbiol. 55, 922-926.

Goddard, R. 1997. Packaging 2004. Pira International.

Godden, B., Ball, A.S., Helvenstein, P., McCarthy, A.J., Penninckx, M.J., 1992. Towards elucidation of the lignin degradation pathway in actinomycetes. J. Gen. Microbiol. 138, 2441-2448.

Golueke, C.G., 1991. Principles of composting. In: The Staff of BioCycle Journal of Waste Recycling. The Art and Science of Composting. The JG Press Inc., Pennsylvania, USA, pp. 14-27.

Golueke, C.G., 1992. Bacteriology of composting. BioCycle 33, 55-57.

Hackett, W.F., Connors, W.J., Kirk, T.K., Zeikus, J.G., 1977. Microbial decomposition of synthetic ${ }^{14} \mathrm{C}$-labeled lignins in nature: Lignin biodegradation in a variety of natural materials. Appl. Environ. Microbiol. 33, 43-51.

Haider, K., Martin, J.P., Rietz, E., 1977. Decomposition in soil of ${ }^{14} \mathrm{C}$ labeled coumaryl alcohols; free and linked into dehydropolymer and plant lignins and model humic acids. Soil Sci. Soc. Am. J. 41, 556-562.

Haider, K., Trojanowski, J., 1980. A comparison of the degradation of ${ }^{14} \mathrm{C}$-labeled DHP and corn stalk lignins by micro-and macrofungi and bacteria. In: Kirk, T.K., Higuchi, T., Chang, H.m. (Eds.), Lignin Biodegradation: Microbiology, Chemistry and Applications, vol. 1. CRC Press Inc., USA, pp. 111-134.

Hatakka, A.I., Pirhonen, T.I., UusiRauva, A.K., 1984. Decomposition of ${ }^{14} \mathrm{C}$-lignins by white-rot fungi. In: Materials of Soviet-Finland Seminar on Bioconversion of Plant Raw Materials by Microorganisms 5-10 December 1983, Tashkent, Scientific Center of Biological Research of the Academy of Sciences of the USSR in Pushchino, Pushchino, pp. 102-110.

Hatakka, A., 1994. Lignin-modifying enzymes from selected white-rot fungi: production and role in lignin degradation. FEMS Microbiol. Rev. 13, 125-135.

Haug, R.T., 1993. The Practical Handbook of Compost Engineering. Lewis Publishers, Boca Raton, USA.

Horwath, W.R., Elliott, L.F., 1996. Ryegrass straw component decomposition during mesophilic and thermophilic incubations. Biol. Fertil. Soils 21, 227-232.
Inbar, Y., Chen, Y., Hadar, Y., 1989. Solid-state carbon-13 nuclear magnetic resonance and infrared spectroscopy of composted organic matter. Soil. Sci. Am. J. 53, 1695-1701.

Inbar, Y., Chen, Y., Hadar, Y., Hoitink, H.A.J., 1990. New approaches to compost maturity. BioCycle 31, 64-69.

Itävaara, M., Venelampi, O., Karjomaa, S., 1995. Testing methods for determining the compostability of packaging materials. In: Barth, J. (Ed.), Proceedings of Biological Waste Management "Wasted Chance". BWM Infoservice, Germany.

Itävaara, M., Vikman, M., Venelampi, O., 1997. Windrow composting of biodegradable packaging materials. Compost Sci. Utiliz. 5, 84 92.

Kane, B.E., Mullins, J.T., 1973. Thermophilic fungi in a municipal waste compost system. Mycologia 65, 1087-1100.

Kirk, T.K., Farrell, R.L., 1987. Enzymatic combustion: the microbial degradation of lignin. Ann. Rev. Microbiol. 41, 465-505.

Kuhad, R.C., Singh, A., Eriksson, K.E.L., 1997. Microorganisms and enzymes involved in the degradation of plant fiber cell walls. In: Eriksson, K.E.L. (Ed.), Advances in Biochemical Engineering/ Biotechnology, vol. 57. Springer, Germany, pp. 46-125.

Leppänen-Turkula, A. 1999. Association of Packaging Technology and Research. Personal communication.

Lin, S.Y., Dence, C.W. (Eds.), 1992. Methods in Lignin Chemistry. Springer, Berlin.

Machuca, A., Durán, N., 1996. Optimization of some parameters influencing Thermoascus aurantiacus growth: effects of ligninrelated compounds. J. Ind. Microbiol. 16, 224-229.

Machuca, A., Milagres, A.M.F., Aoyama, H., Durán, N. 1995. Extracellular component with high phenoloxidase activity from Thermoascus aurantiacus: potentials in pulp and paper applications. Proc. of the 4th Brazilian Symposium on the Chemistry of Lignins and Other Wood Components. Technology Centre, Federal University of Pernabuco, Recife, PE, Brazil, 28 November-1 December 1995.

Maheshwari, R., Kamalam, P.T., 1985. Isolation and culture of thermophilic fungus Melanocarpus albomyces, and factors influencing the production and activity of xylanase. J. Gen. Microbiol. 131, 3017-3027.

Martin, J.P., Haider, K. 1980. Microbial degradation and stabilization of ${ }^{14} \mathrm{C}$-labeled lignins, phenols, and phenolic polymers in relation to soil humus formation. In: Kirk, T.K., Higuchi, T., Chang, H.m. (Eds.), Lignin Biodegradation: Microbiology, Chemistry and Applications, vol. 1. CRC Press, USA, pp. 77-100.

McKinley, V.L., Vestal, J.R., 1985. Physical and chemical correlates of microbial activity and biomass in composting municipal sewage sludge. Appl. Environ. Microbiol. 50, 1395-1403.

Micales, J.A., Skog, K.E., 1997. The decomposition of forest products in landfills. Int. Biodeter. Biodegrad. 39, 145-158.

Mouchacca, J., 1997. Thermophilic fungi: Biodiversity and taxonomic status. Cryptogamie Mycol. 18, 19-69.

Nakasaki, K., Sasaki, M., Shoda, M., Kubota, H., 1985. Characteristic of mesophilic bacteria isolates isolated during thermophilic composting of sewage sludge. Appl. Environ. Microbiol. 49, 42-45.

Nusbaumer, C., Job, D., Aragno, M., 1996. Etude de l'altération par les champignons de l'état physico-chimique des composés lignocellulosiques dans un processus naturel de compostage. Mycologia Helvetica 8, 51-67.

Ofosu-Asiedu, A., Smith, R.S., 1973. Some factors affecting wood degradation by thermophilic and thermotolerant fungi. Mycologia 65, 87-98.

Paatero, J., Lehtokari, M., Kemppainen, E. 1984. Kompostointi. WSOY, Juva (in Finnish).

Pagga, U., 1999. Compostable packaging materials - test methods and limit values for biodegradation. Appl. Microbiol. Biotechnol. 51, $125-133$. 
Rayner, A.D.M., Boddy, L., 1988. Fungal Decomposition of Wood. Wiley, Great Britain.

Riffaldi, R., Levi-Minzi, R., Pera, A., de Bertoldi, M., 1986. Evaluation of compost maturity by means of chemical and microbial analysis. Waste Manag. Res. 4, 387-396.

Robinson, C.H., Dighton, J., Frankland, J.C., Roberts, J.D., 1994. Fungal communities on decaying wheat straw of different resource qualities. Soil Biol. Biochem. 26, 1053-1058.

Rodriguez, A., Perestelo, F., Carnicero, A., Regalado, V., Perez, R., De la Fuente, G., Falcon, M.A., 1996. Degradation of natural lignins and lignocellulosic substrates by soil-inhabiting fungi imperfecti. FEMS Microbiol. Ecol. 21, 213-219.

Romanelli, R.A., Houston, C.W., Barnett, S.M., 1975. Studies on thermophilic cellulolytic fungi. Appl. Microbiol. 30, 276-281.

Rosenberg, S.L., 1975. Temperature and $\mathrm{pH}$ optima for 21 species of thermophilic and thermotolerant fungi. Can. J. Microbiol. 21, $1535-1540$.

Rosenberg, S.L., 1978. Cellulose and lignocellulose degradation by thermophilic and thermotolerant fungi. Mycologia 70, 1-13.

Rüttimann, C., Vicuña, R., Mozuch, M.D., Kirk, T.K., 1991. Limited bacterial mineralization of fungal degradation intermediates from synthetic lignin. Appl. Environ. Microbiol. 57, 3652-3655.

Sharma, H.S.S., 1989. Economic importance of thermophilous fungi. Appl. Microbiol. Biotechnol. 31, 1-10.

Sjöström, E., 1993. Wood Chemistry, Fundamentals and Applications, 2nd ed. Academic Press, New York/London.

Srinivasan, C., D’Souza, T.M., Boominathan, K., Reddy, C.A., 1995. Demonstration of laccase in the white rot basidiomycete Phanerochaete chrysosporium BKM-F1767. Appl. Environ. Microbiol. 61, 4274-4277.

Straatsma, G., Samson, R.A., Olijnsma, T.W., Op den Camp, H.J.M., Gerrits, J.P.G., van Griensven, L.J.L.D., 1994. Ecology of thermophilic fungi in mushroom compost, with emphasis on Scytalidium thermophilum and growth stimulation of Agaricus bisporus mycelium. Appl. Environ. Microbiol. 60, 454-458.
Strom, P.F., 1985a. Effect of temperature on bacterial species diversity in thermophilic solid-waste composting. Appl. Environ. Microbiol. 50, 899-905.

Strom, P.F., 1985b. Identification of thermophilic bacteria in solidwaste composting. Appl. Environ. Microbiol. 50, 907-913.

Stutzenberger, F.J., Kaufman, A.J., Lossin, R.D., 1970. Cellulolytic activity in municipal solid waste composting. Can. J. Microbiol. 16, 553-560.

Thambirajah, J.J., Kuthubutheen, A.J., 1989. Composting of palm press fibre. Biol. Wastes 27, 257-269.

Thambirajah, J.J., Zukali, M.D., Hashim, M.A., 1995. Microbiological and biochemical changes during composting of palm emptyfruit-bunches. Effect of nitrogen supplementation on the substrate. Bioresource Technol. 52, 133-144.

Tomati, U., Galli, E., Pasetti, L., Volterra, E., 1995. Bioremediation of olive-mill wastewaters by composting. Waste Manag. Res. 13, 509518

Tseng, D.Y., Vir, R., Traina, S.J., Chalmers, J.J., 1996. A Fouriertrasform infrared spectroscopic analysis of organic matter degradation in a bench-scale solid substrate fermentation composting system. Biotechnol. Bioeng. 52, 661-671.

Varadachari, V., Ghosh, K., 1984. On humus formation. Plant Soil 77, 305-313.

Vicuña, R., 1988. Bacterial degradation of lignin. Enzyme Microb. Technol. 10, 646-655.

Klopotek, A., 1962. Uber das Vorkommen und Verhalten von Schimmelpilzen bei der Kompostierung Städtischer Abfallstoffe. Antonie v. Leeuwenhoek 28, 141-160.

Waksman, S.A., Umbreit, W.W., Cordon, T.C., 1939a. Thermophilic actinomycetes and fungi in soils and in composts. Soil Sci. 47, 3761.

Waksman, S.A., Cordon, T.C., Hulpoi, N., 1939b. Influence of temperature upon the microbiological population and decomposition processes in composts of stable manure. Soil Sci. 47, 83-114. 